\title{
TEKSTIKESKNE KEELEÕPETUS PÕHIKOOLIS: TEOREETILINE TAUST, VASTUTUSE JAGAMINE JA METOODIKA
}

\author{
MERILIN ARUVEE
}

\begin{abstract}
Annotatsioon. Tänapäeva keeleteadusliku mõtte ja rakenduslingvistika uuemate suundade mõjul on eesti keele õpetamine muutunud tekstikeskseks, püüdes seejuures endiselt tagada ka kirjaliku keele omandamist, k.a õigekeelsust. Teisalt on keeleteaduses tähtsustumas grammatika, mida vaadatakse hierarhiliste ja leksikat hõlmavate tarinditena. Grammatika omandatakse sellisena tekstidest, kuid nüüdisaegne loomulik keskkond ei suuda tagada korrastatud kirjakeele omandamist see on endisest enam kooli vastutusel. Metaanalüütiline kirjandust uuriv artikkel käsitleb selle taustal tekkinud küsimusi, andes ülevaate tänapäevastest rakenduslingvistika teooriatest ja uurimusest, millele tekstikeskne õpetus tugineb, ning kirjeldab eesti keele kui esimese keele õpetuse arenguvõimalusi. Artikkel loob raami uurimustele, mis keskenduvad tekstitööle ja keeleliste konstruktsioonide (k.a sõnavara) suunatud omandamisele eesti keele ning teiste ainete tundides.
\end{abstract}

Võtmesõnad: sotsiolingvistika, emakeeleõpetus (L1 omandamine), kirjaoskus, funktsionaalne grammatika, tekst

\section{Sissejuhatus}

Tänapäeva põhikooli eesti keele õpetuses arendatakse suhtluspädevust ning keeleteadmiste andmise kõrval püütakse lihvida ka keeleoskust. Kõike seda tehakse suuresti autentsete tekstide toel, mistõttu käibivate riiklike õppekavade (PRÕK 2011; GRÕK 2011) eesti keele ainekavu nimetataksegi tekstikeskseks (vt Kerge 2010a, 2010b; Lepajõe 2010). See tuleneb omakorda viimase poolsajandi keelekäsitlustest ja uuematest rakenduslingvistilistest uurimustest ja teooriatest. Niisugusel taustal seatakse artiklis eesmärk rikastada emakeeleõpetust kompaktse teoreetilismetoodilise kirjeldusega tekstikesksest õppeviisist, millele selle valdkonna uurimused tugineda saaksid. Artiklis kirjeldatakse asjakohast teooriat 
metaanalüütiliselt ning esitatakse tänapäevase õpikäsituse taustal peamised tekstikeskse õppeviisi põhimõtted, näited meetodite kohta, sõlmküsimused ning uuringu- ja arenguvajadused.

Esiteks vaadeldakse kirjaoskuse vastutuse sõlmküsimust. Riiklik õppekava näeb nimelt ette, et üks tagatavatest üldpädevustest on suhtluspädevus (Soodla jt 2013: 94), mida siinne artikkel näeb kirjaoskuse kontekstis. See tähendab, et tekstiõpetus käib kõigis ainetes (ib. 97; Kerge 2012: 591), selle elluviimine vajab aga eraldi uurimist ja täpsustamist. Nii on artiklis esmatähtis probleem, milline on kirjaoskuse omandamise teoreetiline taust ja kuidas peaks olema sellekohane vastutus põhikoolis jagatud.

Uurimisprobleemi aitavad lahendada küsimused, millele vastab artikli teine peatükk. Osa 2.1 „Keel omandatakse tekstidest“" kirjeldab, kuidas omandatakse lingvistiline kirjaoskus ning kuidas on see seotud tekstikeskse lähenemisega. Osa 2.2 „Žanrid on dünaamilised“ uurib, kuidas seostub lingvistiline kirjaoskus žanritega ning kuidas õpetada tekstiliike lingvistilise kirjaoskuse toetamiseks. Osa 2.3 ,Kirjaoskuse jagatud vastutus" käsitleb küsimust, miks peaks kirjaoskuse tagama kõigi õppeainete vastutusel, ning toob esile probleemid, mis seda takistavad - otsitakse vastust küsimusele, milline peaks olema uuring, mis neile probleemidele lahendust pakub.

Teiseks võtab artikkel fookusesse tekstitöö ja õigekeelsuse üheaegse omandamise. Näiteks peavad Martin Ehala (2010: 84) ja Krista Kerge (2010a, 2010b) kõige olulisemaks õpetada koos keeleteadmisi, praktilisi oskusi ning tekstitööd. Kersti Lepajõe leiab, et tekstide funktsionaalsest käsitlusest jääb vajaka. Tekstide ja kirjutamise kommunikatiivsetest eesmärkidest õpikutes ei räägita ning teksti ja lugeja suhetele ei pöörata piisavalt tähelepanu. (Lepajõe 2011: 38) Nii võib väita, et tekstide ja õigekeelsuse kui õppevaldkondade ühitamine vajab põhjalikumat uurimist ja suuremat metametodoloogilist tuge. Seetõttu on artikli teine probleem tekstikeskse lähenemise tagamaad ja metoodika, mis aitaks samal ajal žanrija tekstitööga tagada õigekeelsuse valdamist kui võrdtähtsat eesmärki.

Teise uurimisprobleemiga tegeletakse alaküsimusi pidi kolmandas peatükis. Osa 3.1 „Mõtlemise areng ja tekstikeskne lähenemine“ küsib, kuidas toetab tekstikeskne lähenemine mõtlemise arengut, ning vastusena kirjeldab sobivaid meetodeid. Osa 3.2 „Grammatika on tähenduslik“ vaatleb, kuidas nähakse rakenduslingvistikas grammatika ja tekstide seost, ning vastab küsimusele, mida vajab emakeeleõpetus, et tekstikeskne 
õpe ja grammatikapädevus ühendada. Osa 3.3 ,Leksikogrammatika ja korpusekeskne õppeviis“" tutvustab, mil viisil saaks korpuste abil toetada tekstikeskset lähenemist ja keeleteadlikkuse arengut, ning esitab mõne asjakohase näite.

\section{Kirjaoskuse vastutus}

\subsection{Keel omandatakse tekstidest}

Järgnev püüab seostada lingvistilise kirjaoskuse omandamist ja tekstikeskset lähenemist ning kirjeldab teoreetilisi tagamaid selle küsimuse taustal.

Eesti keele õpetus tugineb sotsiokognitiivsele pedagoogikale (Kerge 2010b), mis näeb keelt ühtaegu sotsiaalsuse ja mõtlemise-tunnetuse tegurina ja ühiskonna ideoloogia kandjana. Keel saadab inimest suhetes ja toimingutes, mis väljenduvad tekstidena. Nii on lingvistika huviorbiidis tekstid ja tekstikorpused, sest keelt on hakatud nägema tema toimimises ja muutumises. Sedamööda on keeleõpegi tekstikeskseks muutunud; üksikute osaoskustega tegeledes teadvustatakse, et tekst on alati osa mingist toiminguahelast. (Kerge 2010a)

Keeleõppe keskmes on niisiis tekstitoimingud ja tekstid, mida käsitletakse erinevate ühiskonnas toimimiseks vajalike tekstiliikide ehk Žanritena (Kerge 2010a; Kerge, Uusen 2010), üksteisest lahutamatute ja põimunutena. Põhikooli eesti keele õpikud on tekstirikkad, neis on palju autentse keelekasutuse näiteid, mida loetakse ja mudeldatakse ning mille kirjutamist harjutatakse (vt II ja III kooliastme eesti keele õpikuid: Piits jt 2012, 2013; Ratassepp 2012; Puksand, Bobõlski 2012a, 2012b, 2013, 2014, 2016).

Niisugune praktika tuleneb otseselt keele omandamise teooriatest, mis rõhutavad kõige enam autentsete tekstide kohalolu ja nende kaudu õppimist. Dorit Ravidi ja Liliana Tolchinsky kirjaoskuse raamkontseptsioonis (2002) toonitatakse, et lingvistilise kirjaoskuse ehk keelepädevuse tagab võimalikult eripalgeline ja rikas autentne tekstimaailm. Lingvistilist kirjaoskust, mis on vilumuse kõrgemale astmele jõudnud, nimetavad nad retooriliseks paindlikkuseks (ingl rhetorical flexibility) või retooriliseks kohanemisvõimeks (ingl rhetorical adaptability). See lähtub omakorda Dan Slobini ideest olla retooriliselt väljendusrikas (ingl rhetorically expressive), mis tähendab võimet kohaneda nõudlikumaski suhtlusolukorras, valides sobilikud ja mõtet täpselt edasi andvad keelevahendid (ib.: 420). 
Mahuka lingvistilise korpusuuringu tulemused on samuti tõestanud keelelise sisendi ja väljundi omavahelist seost, sest registritele omased keelejooned kanduvad täiskasvanu tekstide eeskujul üle õpilastekstidesse. Näiteks hakkavad üliõpilased esialgu küll kobades ja eksides kasutama samasuguseid konstruktsioone, mida nad on kohanud teadustekste lugedes. (Biber jt 2002: 461) Kokkupuute tugevnedes meisterlikkus kasvab, ning mida kvaliteetsem ja rikkalikum on õpilase lugemisvara, seda kvaliteetsem on ka tema enda loodud tekst.

Siit selgubki: keeleõpetus on tekstikeskne, sest keel omandatakse terviktekstide kaudu, neid kuulates, lugedes ning kirjutades ja kõneledes ning suhestades ja vahendades.

\section{2. Žanrid on dünaamilised}

Selles osas uuritakse, kuidas tagab tekstiliikide õpetus lingvistilise pädevuse, ning kirjeldatakse metoodilisi võimalusi, mis aitaks tekstiliike keeleteadlikult õpetada.

Tekste võetakse vastu mitmesugustes sotsiaalsetes olukordades ehk kontekstides. Michael A. K. Halliday näeb kontekste, milleks tekste luuakse, situatsioonitüüpidena. Ühes kultuuris kasvanud inimesed tunnevad neid tüüpe (Halliday 1978: 100) ja oskavad nende abil ühiskonnas suhelda. Seega võib žanre näha ühe situatsioonitüübi kultuuriomase tekstilise ilminguna ehk nagu James Martin seda väljendab: ,.. register (hõlmates tegevusvälja, toimeviisi ja -mooduse) kontekstualiseerib keele, mis on omakorda kontekstualiseeritud žanrina"1 (Martin 1997: 7). Seega on keeletoimingud kultuuri- ja olukorrasidusad ning keelevahendite valik neist sõltuv.

Retoorilise žanriteooria koolkonna esindaja Carolyn Miller nimetab žanrit sotsiaalseks aktiks ehk toiminguks (ingl social act, Miller 1984). Žanr pole seega rangelt piiritletud tekst, vaid dünaamiline, muutudes olenevalt olukorrast. Sama nendib ka Hallidayle toetuv Norman Fairclough (2003: 67-73), jagades žanrid situatiivseteks ja üldžanriteks (ingl situational and disembedded genres), mis tähendab, et žanrite üldised mudelid eksisteerivad vaid abstraktsioonina. Reaalses suhtlussituatsioonis võtavad žanrid täpse kuju olenevalt olukorrast, eesmärgist ja vastuvõtjast. Nii ei

${ }^{1}$ Merilin Aruvee tõlge. Originaal: ,.. register (encompassing field, tenor and mode) contextualizes language and is in turn contextualized by genre". 
saagi õpetada mingeid kindlaid žanrimudeleid (Miller 1984: 165; Dean 2008: 3), vaid need tuleb olukorra ja eeskuju järgi taasluua. Tingimata on vajalik tutvuda võimalikult paljude eri laadi žanrinäidetega. Mõttetu oleks kirjutada uudist etteantud skeemi alusel, kui pole loetud mitmesuguseid uudisetekste eri liiki meediumites ja suhtlusolukordades, või rääkida intervjuust, teadvustamata, et see on üldistus, mis hõlmab lehe-, raadioja teleintervjuu kõrval värbamisintervjuud tööjõu- või tööotsingul jpm.

Žanrite valdamine tähendab paindlikku keelekasutust ja head olustikutunnetust (Raidlepp 2015: 12), seetõttu peab emakeeleõpetuses arendama Žanriteadlikkust, mis kujuneb võimalikult paljusid eri liike tekste vastu võttes. Selle kõrval ei tohi unustada žanri toimingulist olemust, mis suunab analüüsima eri autorite ja ise oludes loodud sama liiki tekste.

Just žanririkkus on ka leksikogrammatika omandamise põhialus. Joan Bybee väidab, et keel on (nagu Hallidaygi arvates) kasutusega ladestuv kogemus. Sujuv keelekasutus ei tugine mitte grammatikale selle abstraktses tähenduses, pigem moodustavad varasemad sõnumid meie peas mahuka lao, mida kasutatakse uute sõnumite loomeks ja mõistmiseks. (Bybee 1998: 421). (Leksikogrammatikast pikemalt all.) Kui ladu on kehv, ei saa teha piisavalt täpseid valikuid ning sõnum ei pruugi mõjule pääseda. Rikkalik keeleladu ei jäta aga sõnumikoostajat eesmärgi elluviimisel hätta.

Žanriteadliku keeleõppe metoodika keskendub autentsetele tekstidele, mida uuritakse põhjalikult: vaadeldakse nende sotsiaalset konteksti ja eesmärki; võrreldakse tekste, leitakse ühis- ja erijooni, hinnatakse mõjuvust, rolli ja vastukaja ühiskonnas (Dean 2008). Žanrite põhjalik analüüs aitab õpilastel näha ja järeldada, kuidas iga kindel olukord teksti mõjutab.

Selle metoodika arendajad Peter Knapp ja Megan Watkins (2010: 167-170) esitavad ühe viisi, kuidas žanri-ja grammatikaõpetus ühendada 5. klassis.

Toitumisteema juures vaadeldakse emakeeletunnis retsepte. Uuritakse retsepti pealkirja, teksti eesmärki ning tutvutakse retsepti ülesehituse, info esituse ja järjestusega. Vaadatakse illustratsiooni ning arutletakse selle eesmärgi üle.

Žanri õppimist alustatakse teksti ülesehituse analüüsist ehk liigutakse laiemalt kitsamale: esmalt luuakse kontekst, seejärel analüüsitakse keelevahendite valikut. 
Järgnevalt loetakse retsepti tekst läbi. Õpetaja palub joonida tegusõnad, mis kirjutatakse tahvlile (jahuta, kuumuta jne). Uuritakse, milliste nimisõnade kohta tegusõnad käivad ehk leitakse sihitised (jahuta riis, kuumuta vedelik). Õpetaja püüab suunata õpilasi märkama tegu- ja nimisõna vahelist seost.

Vanemates astmetes võib siinkohal lauseliikmeid määrata ning suunata ka öeldise ja sihitise vahelist seost märkama; analüüsida saaks osa- ja täissihitise kasutust, et näidata, kuidas täis- ja osasihitise puhul tähendus erineb (vrd lisa veidi suhkrut; lisa suhkur).

Nüüd leiavad õpilased tegevust täpsustavad sõnad ehk viisimäärused (sega ettevaatlikult, silu hoolikalt) ning põhjendavad nende sõnade vajalikkust.

Siin võib paluda teksti ette lugeda ilma täpsustusteta ning arutleda, mis juhtuks, kui neid sõnu ei oleks, või lasta ette näidata, kuidas käib ettevaatlik segamine ja kuidas lihtsalt segamine.

Viimaks otsitakse välja tegevuse järjestust edasi andvad sõnad ehk ajamäärused (esmalt, viimaks). Õpilased kirjutavad leitud sõnaliigid kolmeveerulisse tabelisse. Koduse ülesandena tuleb tabeli abil kirjutada üles õhtusöögiretsept, mida järgmises tunnis analüüsitakse.

Kirjutamisülesannet ei anta ilma olukorda kontekstualiseerimata, samuti on oluline kirjutamiseesmärk ja keelevahendite valik. Järgmises tunnis analüüsitakse tehtud töid koos.

Pärast kirjutiste kompositsiooni ülevaatamist palub õpetaja kindlaks teha, kas tekstis esineb sina-vormi. Uuesti vaadeldakse eelmise tunni retsepti ning mõeldakse teksti vastuvõtjale ja sellest lähtuvale verbikasutusele. Õpilased peavad põhjendama verbi vormi valikut, ütlema, miks pole sina-vormi vaja ning kuidas antakse edasi teksti vastuvõtja isikut. Korrigeeritakse tekstid ja tehakse üldistus nii retsepti kui ka juhendava tekstitüübi kohta.

Näha on, kuidas žanriteadlikkus ja grammatikapädevus käivad käsikäes. Õpitakse dialoogivormis: küsimuste toel avastatakse, kuidas on grammatilised valikud teksti eesmärgi teenistuses.

Samasugust mudelit saab korrata teistegi tekstiliikide puhul. Kõige olulisem on õpetajal läbi mõelda, mis on teksti eesmärk, kes on selle vastuvõtja, ning eeltööna vaadelda teksti grammatilisi tunnusjooni ja viisi, kuidas siduda tekstivalik aine eesmärkidega. 
Žanrite kui korduvate situatsioonitüüpide õpetamisel ei tohiks unustada konventsionaalsust ja olukorrakesksust. Teksti analüüsides peaks lähtuma teksti üldisest kontekstist, vastuvõtjast, suhtluseesmärgist ning ühes kompositsiooniga peaks käima ka keelevahendite valiku analüüs, mis žanri olemuse määravad. Ülaltoodud väike näide aitab mõista põhimõtet, kuidas lingvistilist kirjaoskust toetada.

\subsection{Kirjaoskuse jagatud vastutus}

Järgnevalt keskendutakse küsimusele, miks peaks kirjaoskust õpetama kõigi õppeainete vastutusel. Antakse ülevaade probleemidest, mis seda takistavad, ning kirjeldatakse uuringut, mis sellele probleemile lahendust pakuks.

Õpilased puutuvad valdkonniti kokku mitmesuguste žanritega, sest suulise klassitöö kõrval omandatakse valdav osa õpitavast just eri ainete (kirjakeelseid) tekste lugedes ja kirjutades. Olukord on laiemalt teadvustunud alates sellest, kui hakati propageerima ainekirjaoskust, millega muutus emakeeleõpetuse vastutusala, ilma et tekstiõpetuse ja kirjakeele õpetamise metoodika muudes ainetes oleks tagatud (vt Krogh 2012: 2-4). Eestis peetakse vajalikuks, et teisteski ainetes juhitaks tähelepanu õigekirja- ja grammatikareeglite normipärasele rakendamisele (Soodla jt 2013: 101), kuigi nende õpetamine ja õigekeelsuse peenemad nüansid on keeleõpetuse ülesanne. Esimese aasta üliõpilaste keeleoskuse uuringutes soovitatakse tekstitöö ja funktsionaalse keeleoskuse arendamine lisada kõigi erialade õpetajakoolituse kavadesse, mida seni tehtud ei ole (Ehala jt 2010: 65, 2015: 70). Kuidas seda aga teha, kui pole teada, mismoodi peaksid keelt käsitlema teiste ainete õpetajad või millist liiki tekstide omandamist saab emakeeleõpetaja teiste ainete osana eeldada?

Euroopa keeleõppe raamdokument ${ }^{2}$ (EKR 2007) küll nimetab tekstiliigid, mida peaks keeleõppija tundma, et ühiskonnas täisväärtuslikult

2 Krista Kerge (2007) leiab, et EKR haakub emakeeleõpetuse muutunud olemusega, sest praegune emakeeleoskaja on 20 aasta taguse ajaga võrreldes teistsuguses olukorras ning varem loomulikult omandatud tekstitoimingud on taandumas, mistõttu peab selle osa kirjaoskusest tagama kool. Eestis pole harjutud mõtlema, et Euroopas omandatakse kogu haridus emakeelest olenemata ühes klassiruumis. Nii pakub EKR sobiva raami ka emakeeleõpetuse jaoks, sest ühiskonnas tegusa liikmena peavad riigikeeles toimima kõik olenemata sellest, kas eesti keel on emakeel või teine keel. 
toimida (samasugust loendit sisaldab ka põhikooli eesti keele ainekava (PRÕK 2011), millest lähtuvad õpikud), kuid ei ole kindlaks määranud, kuidas vastutus kirjakeele omandamise eest tegelikult jaotub. Ellen Kroghi uurimisrühm on uurinud tekstide kasutuse ja loome õpetamist ning kvalitatiivselt analüüsinud Taani, Norra ja Rootsi õpetajate päevikuid, kusjuures õpetajaid konsulteeriti uuringu käigus pidevalt. Krogh leidis kolm eesmärgiti erinevat õpetamisdiskursust: strateegiline, rituaalne ja suhtluskeskne. Kõige enam varieerib tekstitööd suhtluskeskne õpetaja, pürgides tekstitöö õpetamisel harituse saavutamise poole (Krogh 2012: 25). Tekstitööd mõjutavad seega peamiselt õpetaja seatud eesmärgid, ainuüksi tekstivalik ei peegelda, mis meetodil ja eesmärgil teksti käsitletakse.

Eestis oleks selle taustal vaja täpsemalt uurida, kas ja milliseid tekste eri ainete õpetajad kasutavad ja millest see oleneb. Milline on tekstide kasutamise ulatus, õppe-eesmärgid, tekstitöö juhendamise käik, ülesanded ja selle õppetöö tulemused kõigis ainetes?

Sellise uuringu eesmärgiks võiks seada tekstitöö sisu täpsustamise, mis annaks teavet tekstiliikide õpetamise vahekorra ja õppetegevuste kohta, toetaks teiste ainevaldkondade tekstitööd ning aitaks arendada jagatud vastutusel kirjaoskuse metoodikat. Peamine uurimisküsimus on: kuidas kasutatakse põhikoolis autentseid terviktekste? Alaküsimustena tuleks saada vastused selle kohta, millest lähtub õpetaja tervikteksti valikul; mis eesmärgil teksti või selle terviklikku katkendit kasutatakse; mis rollis on tekst tunnis: kas käsitlus piirdub infoallikana või on tekst õppimise objekt; milliseid tekstitöö ülesandeid õpetaja annab ning mis on õpitegevuse eesmärk, tulemus ja kuidas hindab õpetaja saavutatut.

Neile küsimustele annaks kõige selgema vastuse etnograafilist laadi uurimus, mis vaatleks tekstitööle keskendunud koolitunde ja tunnimaterjale või analüüsiks õpetajate päevikuid (vt Ellen Kroghi uuringust eespool). Andmeid saaks täiendada etnometodoloogilise uuringuga, intervjueerides õpetajaid, paludes neil vaadeldud tunde kommenteerida ning tunni eesmärke, teksti rolli, õpilaste tegevust ja tulemusi ning kogu õppeprotsessi selgitada. See aitaks kinnitada tekstivaliku kriteeriume ja didaktilisi eesmärke. Eelkirjeldatud uurimuse tulemusel joonistuksid välja tekstikäsitlusviisid koolitunnis ning nende didaktiline tagamaa. Uuring võimaldaks järeldusi teha nii õppekava- ja metoodikaarenduse kohta kui ka täiendada õpetajakoolituse kavasid ülikoolides. 
Eelnev arutlus ilmestas, kuidas lingvistiline kirjaoskus areneb inimese tekstimaailma rikkuse najal. Et aga tekste omandatakse igalt elualalt, peaks neid koolis kõigi õppeainete vastutusel õpetama. Selle idee jaoks oleks aga vaja ülal pakutud uurimus teoks teha.

\section{Tekstitöö ja õigekeelsuse üheaegne omandamine}

\subsection{Mõtlemise areng ja tekstikeskne lähenemine}

Siinkohal näidatakse, kuidas tekstikeskselt keelt õpetades areneb ka mõtlemine, ning tutvustatakse lähemalt meetodeid, mis seda toetavad.

Nüüdisaegne õpetus tugineb konstruktivistlikule pedagoogikale, mille järgi uued teadmised ehitatakse üles varem individuaalselt omandatule ehk tuntule (Richardson 2003: 1; Kikas 2013: 27; Ehala jt 2014: 25; Kalantzis, Cope 2016). Samast lähtekohast on võrsunud ka muutunud õpikäsitus (EEÕS 2020), mis räägib innovaatilisest õpikeskkonnast ja õpilaskesksusest, väljendudes aktiivõppemeetoditena, nagu näiteks projekt-, probleem- ja avastusõpe, mille puhul õpetaja tegutseb juhendajana ning õpilased juhivad ja suunavad õppimist ise (Viive-Riina Ruusi ettekanne 20153; Põlda, Aava 2016).

Aktiveeritus tähendab ka mõtlemise aktiivsust. Kognitiivses arengus eristatakse tava- ja teadusmõistelist mõtlemist, millest viimane tähendab kõrgemat taset ehk võimet abstraktsest mõistest ja selle definitsioonist aru saada ning osata mõistet kategoriseerida. Teadusmõistete omandamine käib olemasolevate tavamõistete toel ehk lihtsustatud teadmised korrigeeritakse ja viiakse järgmisele tasemele. Teadusmõiste omandamiseks on vaja uus teave enda omaks mõelda. Seda toetavad just nimelt erinevad aktiivõppemeetodid ja ühine arutelu tunnis. Et aga uus info mõtestatakse mõtlemistaseme kohaselt, võidakse keerukas ja arengutasemele mittevastav teave pähe õppida või siis kohandatakse senise kogemusega, mis võib tähendada lihtsustatud või vääral kujul mõistmist. (Kikas 2013: 27-29) Krista Kerge (2005: 27-58) toob esile sama: ühiselt tekstide üle arutledes on kasu mitmekordne, sest samu tekste võetakse vastu eri alustelt; igasugune dialoog klassis on õppimine ja areng.

3 Viive-Riina Ruusi ettekanne „Muutunud õpikäsitlus“ ühenduse Loovharidus seminaril „Loovharidus Eesti moodi IV. Õpetaja on loov“ 7. märtsil 2015; http:// loovharidus.ee/muutunud-opikasitlus/. 
Õpilase vähese aktiveerituse pärssivat mõju mõtlemisele näitab tänapäevalgi asjakohane Nikolai Remmeli uurimus, kus leitakse, et eesti keele tundides on õpilased norrgalt hõivatud, st nende ajud ei tööta piisavalt (Remmel 2008/1971: 88). Mitmed Remmeli informandid kurdavad igavust, sest emakeeletundides toimub tuim reeglite päheõppimine (Remmel 2008/1971: 110-116) - õpitakse mõtestamata. Hilisemad uuringud ei anna rõõmustavamaid tulemusi (Tärk 2008; Roio 2011). Remmeli uuringut korranud Tiina Tärk nendib, et kehvade õpitulemuste põhjused on reeglite rohkus, õpilaste loid ja pealiskaudne suhtumine ning nõrk töö- ja mõttepinge. (Tärk 2008) Maire Roio tulemuste järgi on õpilaste arvates eesti keele tunnid üpris igavad, mitte kuigi rasked, ent vajalikud (Roio 2011: 53-54). Raskeimaks peetakse reeglite õppimist (ib.: 65), kuid lisanäidete toomine on põnev $(i b .: 41)$. Veebiotsingud on aga meelistegevus nii kirjanduses kui ka keeles (ib.: 62).

Näib, et Remmeli ligi poolsajandi tagune väide kehtib nüüdki. Remmel rõhutas, et keeletunde aitab aktiveerida loomuliku keeletaju kasutamine: tavamõisteline mõtlemine keelest viiakse teadusmõistelisele tasandile. Selleks sobilik õppeviis oleks keelenäidete uurimine ja reeglite avastamine, s.o induktiivne õppeviis. (Remmel 2008/1971: 118) Martin Ehala sekundeerib Remmelile ja küsib provotseerivalt: kui palju abstraktset grammatikaõpetust üleüldse vaja on? Ta leiab, et teaduslikul tasemel käsitlust toetaks analoogia tõhusam rakendamine. (Ehala 2012) Lev Võgotski mõtlemise teooriat arendanud psühholoog Aaro Toomela toob aga esile, et kuigi me ei vaja praktiseerimiseks teooriaid ega abstraktsioone, aitavad need meil nähtusi paremini mõista, kategoriseerida ja süstematiseerida ning edasi arendada (Toomela 2013:21-22; 9). Sellest tuleks keeleõppeski analoogia ja induktsiooni kõrval juhinduda, lähtudes lapse olemasolevatest teadmistest ning juhtides ta mitmesuguste tekstinäidete toel abstraktseid keeleteadmisi avastama.

Emakeeletund ei tohiks olla koht, kus laps oma loomuliku keeletaju reeglirägas unustab ning edaspidises elus tekste koostades ebaleb, vaid vastupidi: loomulik keeletaju peaks tugevnema ning otsimis- ja avastamispüüd saama innustust. Nii võiks õpilased esialgu oma sõnu kasutades ja loomuliku keeletunde järgi õpetaja esitatud näidetes mingit seaduspära näha, arutleda omavahel õpetaja suunamise toel. Isegi kui esialgu ei osata õigeid mõisteid kasutada, ei tuleks põhjendusi valeks pidada, vaid juhatada nähtuse kohta täpsemat infot otsima. Tänapäevased keeleallikad pakuvad 
selleks küllalt võimalusi, nt Keeleressursid, Keeleveeb, e-keelenõu, Eesti Keele Instituudi jt veebilehed, WordNet, rakendustena eesti keele süntesaator, tesaurus, emotsioonidetektor. Veebiotsingu tulemusi kokku võttes saab õpetaja õpilastes kujundada uuritud nähtusest teadusmõistelise arusaama.

Ilmestagu eelnevat näide, kus aastaid Kiltsi põhikoolis eesti keele õpetajana töötanud Mari-Vivian Ellam kirjeldab ${ }^{4}$, mismoodi nägi välja tund, kus õpilased esimest korda reegliõppimisel induktsiooni ehk iseavastamist kasutasid ning kaashäälikuühendi reeglit õppisid.

Esiteks palusin õpilastel jagada sõnad kahte rühma. Üks rühm sõnu oli täis- ja teine kaashäälikuühendiga. Esmalt tuli mõelda välja, mille põhjal on sõnad rühmades. See saavutati.

Häälestuseks on õpetaja valinud rühmitamisülesande. Suur sõnadevaheline erinevus aitab eesmärgi kergesti saavutada ning nii on tähelepanu haaratud ja valmisolek õppimiseks olemas. Õpetaja liigub edasi raskema ülesandega, et õpilastele parajat mõttepinget pakkuda.

Jagasin õpilastele sõnapaarid (homme-homne, lõpp-lõplik) ning küsisin, mida nad märkavad. Läks natuke aega, kuni nad taipasid, et ühes sõnas on kahekordne, teises ühekordne häälik. See ei tulnud üldse kergelt. Kuulsin enne igasuguseid huvitavaid vastuseid.

Soovisin teada, miks on osades sõnades ühekordne häälik. Vastusega läks pikalt aega. Viis korda pakuti eri hetkedel, kuna sõna on mitmuses (üks ka oli: kuppel-kuplid, viitasin, et teised ju ei ole). Püüti läheneda sisuliselt, nendel hetkedel, kui üldse püüti, sest nad jäid ootama, millal tunniga edasi minnakse.

Kui ülesanne läheb raskemaks, kaotavad õpilased huvi, kuigi on selgelt näha, et õpilased püüavad mõelda. Kui tulemuseni ei jõuta, jäädakse ootama, millal õpetaja selgitama asub ning tunniga edasi läheb. Niisiis on õpilased harjunud, et õpetaja on tunnis aktiivsem osapool ning see, kes uut õppesisu avab ja selgitab.

Andsin vihjeid - see ei ole seotud sisuga, vaid häälikutega. Vastuseid ei tulnud.

${ }^{4}$ 2016/2017. õa sügissemestril peetud „Tekstikeskse keeleõpetuse“ loengu järel jagas magistrant Mari-Vivian Ellam meilitsi oma kogemust induktsiooni kasutamise kohta tunnis. Üliõpilase nõusolekul on esitatud väljavõtted tema meilist. 
Õpetaja püüab õpilaste mõttetegevust ergutada, kuid õpitav jääb kättesaamatuks. Ta astub radikaalse sammu.

Ütlesin: „Me ei jätka, kuni see on välja mõeldud.“ See aitas: järsku mõisteti, et mina ei jokuta, vaid asi on neis. Silmaga paistis, kuidas ükshaaval aktiviseeruti ja pingeliselt mõtlema hakati.

Hoolimata sellest, et õpetaja seekord vastuste andmisest keeldub, ei ole õpilastel siiski võimatu ise lahendust leida. Seega ei tasu õpilaste võimet iseavastamisel alahinnata.

Nad sõnastasid end kohmakalt ja valesti, järsku said nad justkui aru, et ei tea sedagi, mis see kaashälikuühend täpselt on. Õpilased mõtlesid pingsalt, ent järeldusele ei jõutud. Kuid nad püüdsid päriselt aru saada.

Kuigi selles tunni etapis võib juba tunduda, et õigem oleks õpetajal selgitama asuda, ei ole see siiski nii. Õpetaja jälgib arutelu ning ootab sobivat momenti sekkumiseks ja suunamiseks. Näeme, kuidas õpilastel puuduvad õiged teadusmõisted enese väljenduseks.

Lõpuks tuli väike valguskiir ühelt õpilaselt, kelle emakeel on albaania keel: seal ei ole teist $m$-i, sest $m$ on $l$-i kõrval. Haarasin sellest. Küsisin iga sõna kohta tahvlil, milline täht ei luba algvormis olevat kaashäälikut kahekordselt kirjutada.

Induktsioon kaasas ka teise emakeelega õpilase, sest järeldusviis on üleüldine ning selle näite puhul ei ole vaja sügavaid teadmisi õpitavast keelest, vaid loogikat.

Sõnastasime koos reegli. Selleks pidime uuesti meelde tuletama, mis on kaashäälikuühend. Kui äge ja õpetlik tund see oli! Ma sain teada, et neil on näiteks segadus klusiilide ja kaashäälikutega ja nägin, et selline ise avastada laskmine on ülihea õpetusviis.

Õpilased jõudsid selle tunni jooksul tavamõiste juurest teadusmõisteni. Samuti aitas induktsioon ja ühine arutelu õpetajal sügavamalt näha, mis on puudulike teadmiste taga. Nii saab õpetaja meetodeid ja õppetegevusi paremini kavandada, võttes arvesse õpilaste tegelikke vajadusi. Ebaedu põhjuseks on niisiis õpilase passiivne roll tunnis ja ülevastutav õpetaja. Deduktiivse meetodi vahetamine induktiivse vastu aitab areneda nii õpilasel kui ka õpetajal. Tunni lõpul on õpetaja väga olulise tunnetuse võrra rikkam. 
Ma olen viis aastat V klassis kaashäälikuühendi reeglit õpetanud ja alati imestan 9. klassi eksamiks neid valmistades, et sellest poleks nagu kuuldudki. Tuleb välja, et nad ei olegi kunagi üldse aru saanud, millest juttu on. See pilk õpilase silmis, kui tal tõesti „koidab“, on õpetajana nii nauditav vaadata. Ma polnud seda ammu näinud.

Eelnevast on selgelt näha, et avastamine, õpilase aktiveerimine, õpitava enda omaks mõtlemine, nagu Kikas eespool toonitab, on mõistmise võti.

Teiseks õpilaskeskseks meetodiks on induktsiooniga haakuv avastusõpe, mille algataja Jerome Bruner peab oluliseks õppimisteguriks inimloomule omast uurimis- ja nuputamistahet (Bruner 1961: 1). Avastusõpe lähtub õpilase huvist ja püstitatud küsimusest, mille vastus saadakse iseseisvalt ja eesmärgipäraselt mingit nähtust uurides, õpetaja roll on seejuures suunav ja abistav. Avastusõpe ei tähenda üksnes uurimistöid, vaid ka üksikuid ülesandeid või õppetegevusi.

Elektroonilisi keeleallikaid võib kasutada mis tahes küsimuse tekkimisel klassis või ka mahukama uurimistöö tegemiseks. Õpitavat uurides saavad õpilased end tegevuses hoida.

Vabariigi presidendi 24. veebruari kõne käsitluse juures sobiks pärast teksti läbi lugemist ja üldise arvamuse kujundamist uurida ka teksti võtmesõnu. Viimase teada saamiseks tuleb tekst kopeerida mõne sõnasagedusrakenduse aknasse (näiteks lehel webcorplive.co.uk) ning leida kõige sagedasem sõna. Vastuseks tuleb „ei“. Järgnevalt võib ühe sõna asemel vaadelda kahesõnaliste konstruktsioonide esinemust. Siit edasi võib tegevus jätkuda võtmesõnade ümbruse ja lausete uurimisega, mille põhjal saab teha sügavamaid järeldusi, kuidas teksti vormivalik sisu loob. Võrdluseks võib praeguse presidendi kõne võtmesõnu kõrvutada president Ilvese või Meri omadega ning leitu üle arutleda.

Ka vormiõpetus annab küllalt võimalusi isetegutsemiseks. Õpilased võivad veaohtlike sõnade kohta teha korpuses või Google'is otsinguid. Sõnaraamatust õigete vastuste leidmise järel mõistavad õpilased, et guugeldamise asemel aitavad paremini hoopis keeleallikad.

Harva või vananenud sõna mõistmiseks võivad õpilased uurida vanu sõnastikke, vana kirjakeele või ilukirjandustekstide korpust. Niisugune tegevus ei võta kaua aega, kuid parandab keeleteadlikkust ja seab õpilased aktiivsesse rolli, kujundades teadlikumad ja aktiivsed keelekasutajad, kes oskavad ise vastuseid leida ja keelt avaramalt näha. 
Et kasutatavast keelest mõtlemine jõuaks teadusmõistelisele tasemele, peaks tunnis olema kesksel kohal tekstide avastamine ja suhtluskoostöö, mida saab ellu viia mitme mõtlemist aktiveeriva meetodiga, nagu näiteks induktsioon ja avastusõpe, mis aitavad soorituspinget üleval hoida.

\subsection{Grammatika on tähenduslik}

Allpool püütakse rakenduslingvistika teooriate najal selgitada grammatika ja tekstide seost ning tuua esile, mida vajab emakeeleõpetus, et tekstikeskset õpetust koos grammatikapädevusega rakendada saaks.

Tänapäeva rakenduslingvistika ei näe grammatikat enam tekstist eraldatuna. Funktsionaalse keelekäsitluse looja Michael A. K. Halliday nimetab grammatikat semantiliseks, leides, et grammatika on tähenduse loomise vahend (Halliday 2005/1979). Tema teooria järgi valitakse keelelised konstruktsioonid teadlikult teksti eesmärki silmas pidades ( $i b$.). Halliday järgi on keelel kolm põhi- ehk metafunktsiooni: kujutus- ehk tähistusfunktsioon (ingl ideational function), suhtlusfunktsioon (ingl interpersonal function) ja tekstuaalne funktsioon (ingl textual function) (Halliday 2005: 2; Halliday, Matthiessen 1999). Tekstuaalne funktsioon hõlmab teist kaht, sest tekstide abil omandatakse keelt, tunnetatakse ja suheldakse, kuid ta sisaldab ka viisi, kuidas oma mõtet tekstina mõistes seostatakse (kompositsioon ja sidendus). Iga sõnum või tema osa kätkeb neid funktsioone, millest omakorda lähtuvad valitud grammatilised konstruktsioonid.

Halliday nimetab süntaksi ja sõnade vahelist seost leksikogrammatikaks (Halliday 1985), kuna sõnade ja grammatiliste struktuuride vahel kordub sageli kindel esinemismuster (Hunston, Francis 1999). Sama fenomeni on suulise ja kirjaliku inglise keele korpusuuringuga kirjeldanud Douglas Biber. Mitmemõõtmelise analüüsi (ingl multi-dimensional analysis) abil tuvastas ta registritele omased grammatilised erijooned, mis omakorda moodustavad avaramaid lingvistilisi dimensioone (Biber 1988; vt ka Hennoste, Muischnek 2000). See kinnitab Halliday suunda: grammatika ei seisa tekstist ega sõnadest lahus (Halliday 1975, 2005; Sinclair 1991; Hunston, Francis 1999). Eesti keele tekstivaldkondi analüüsinud Heidi Meieri (2003) ning Krista Kerge ja Hille Pajupuu jt uuringud (vt tulemusi viidatuna Kerge, Pajupuu 2010) kinnitavad Biberi leide: tekstivaldkonnad erinevad teatud grammatiliste tunnuste poolest. Eri allkeelte 
tekstiliikide ja mitut liiki autoritekstide rühmitus formaalsuse (ühemõttelisuse), leksikaalse tiheduse, nominaalsuse, verbilisuse ja stiilidominandi (ladususe) järgi näitab, kuidas žanr kui sotsiaalse olukorra konfiguratsiooni väljendusviis keelevahendite valikut kõige olulisemal määral mõjutab (Kerge, Pajupuu 2010; Puksand, Kerge 2012), olenedes samas tugevasti noore keeleomandaja east (Kerge jt 2014a, 2014b).

Leksikogrammatilisi seoseid tekstides on korpusemeetodil uurinud ka Csilla Weninger (2010), Randi Reppen ja Shelley Staples (2016) jt, kelle töö tulemused kirjeldavad tekstide grammatika ja sõnavara seoseid, mis aitavad grammatikat paremini mõista (Peppard 2010).

Randi Reppen ja Jack Richards arvavad, et hoolimata tänapäevastest arusaamadest keeleteadmiste kohta on grammatikaõpetus endiselt päevakorral, sest pigem keskendutakse grammatilistele teadmistele, mitte grammatilistele oskustele, kuigi mõlemad moodustavad grammatikapädevuse (Reppen, Richards 2014: 5). Grammatilise oskusena nähakse siinkohal suhtluspädevust. Nii õpetades ei keskenduta mitte üksikutele sõnadele ega lausetele, vaid tekstile, sest muidu omandatakse küll grammatilised teadmised ehk reeglid, kuid need ei haaku autentse igapäevakeele ja suhtlusega, mistõttu ei osata grammatikareegleid suhtluse huvides eesmärgipäraselt kasutada. Et selline teadlikkus ja oskus tekiks, tuleks grammatikat käsitada osana tekstiloomest (Ehala 2010: 2; Reppen, Richards: 2014: 6), teiste sõnadega: arendada keelekasutaja retoorilist paindlikkust kui oskust keelevahendeid teadlikult hinnata ja valida (Ravid, Tolchinsky 2002).

Kuigi põhikooli õpikud (vt nt Puksand, Bobõlski 2012a, 2012b; Ratassepp 2012) kasutavad üha enam induktiivset reegliõpetuse meetodit, mida on juba mitukümmend aastat efektiivsemaks peetud (Remmel 2008/1971: 121; Ehala 2012: 623-624), ja on näiterohked, võib eesti keele õpetuse probleemkohaks pidada seda, et siiski ei süveneta piisavalt žanrite lingvistilisse eripärasse ehk olukohasesse kompositsiooni ja stiili: iseäralikke grammatilisi jooni, tunnuseid ja eriomast sõnavara analüüsitakse ning uuritakse vähe. Pigem ei osata grammatikat, sh lauset, muuteparadigmat ja vormimoodustust, otseselt tekstiliikidega seostada, mida kinnitab ka näiteks Margaret Raidlepa magistritöö (2015), kus ühtlasi leitakse, et ligi pooled õpetajad eelistavad liikuda tekstinäitest reegli juurde ehk kasutavad induktsiooni (ib.: 61). See kõik osutab, et õpetajad mõistavad tekstikeskse lähenemise üldisi printsiipe, kuid induktiivne keeleõppemetoodika vajaks 
tõhusa teadliku keelekasutuse nimel veel arendamist - kasutaja keeleteadlikkus on kirjakeele definiitseid tunnuseid (Kerge 2003).

Kuna gümnaasiumis (GRÕK 2011) on süsteemne grammatikakäsitlus asendatud vajaduspõhisega (vt Kerge 2010b; Ehala jt 2014: 9), siis peaks just põhikoolis keskenduma keelesüsteemi kirjelduse kõrval grammatikale autentsetes tekstides, uurima ja avastama grammatika rakendumist tekstiliikides, lastes õpilasel konstrueerida nii lingvistilised teadmised (Ehala 2010: 2) kui ka osati neile toetuva žanripädevuse.

Teksti ja grammatika koosõppe metoodika kui üks kitsaskohti vajab ületamiseks täpsemat tekstiliikide ja grammatiliste konstruktsioonide vaheliste seoste kindlakstegemist.

\subsection{Leksikogrammatika ja korpusekeskne õppeviis}

Järgnevalt tutvustatakse korpusekeskset õppeviisi kui tekstitöö ja keeleteadlikkuse toetajat. Antakse ülevaade uuringutest, mis selle meetodi tõhusust tõestavad, ning esitatakse meetodite näiteid.

Gena Bennetti (2013: 7) järgi võimaldavad korpused empiirilist analüüsi loomuliku keele kohta; annavad ligipääsu mahukale ja süstematiseeritud tekstikogule; kasutavad analüüsiks arvuti abi ning pakuvad mitmesuguseid kvalitatiivse ja kvantitatiivse analüüsi viise. Korpused võimaldavad mahukat andmeanalüüsi, mida käsitsi oleks väga raske teha. Korpuste abil saab õppida fraseoloogiat, leksikogrammatikat, registrierinevusi, eri eesmärkidel kasutatavat keelt ja üksikuid keelenüansse. (ib. 8-11)

Korpusuuringute tulemused pakuvad koolikonteksti jaoks, nt õpikukoostajatele, vajalikke andmeid ning võimalust autentset keelt uurida. Inglise keele kui teise keele õpetuses on korpuste kasutamisest kirjutatud juba 1980. aastate lõpul (Johns 1988). Mitmes uuringus keskendutakse korpusekeskse keeleõppe metoodikale ning selle efektiivsusele (Wichmann jt 2013). Cambridge'i keeleõpikute koostamisel on ligi kümmekond aastat lähtutud korpusuuringutest, et tuua õpikutesse autentse keele näiteid ja ilmestada seda, kuidas mingi keelekonstruktsioon suhtlussituatsioonis avaldub (vt Carter jt 2000).

Kahjuks ei jõua korpusuuringu tulemused ega ka leksikogrammatiliste seoste kirjeldus siiski sageli koolitundi ega õpikutesse (Koprowski 2005: 331; Kitsnik 2006: 104). Mark Koprowski uuris kolme keeleõpiku leksikaalseid fraase ja leidis, et kolmandik neist on juhuslikult valitud ega ole 
keeleõppe seisukohalt olulised, nt grammatiline funktsioon (Koprowski 2005). Nii võib keeleõppe kuivaks ja mõttetuks muuta, elavad keelenäited aga turgutaks loomulikku keeletunnetust. Õpikukoostajatel on kohustus pakkuda autentset keelelist materjali ning võtta arvesse lingvistiliste uurimuste tulemusi (Sinclair 1991: 39; Koprowski 2005: 331).

Korpusotsingud ja leksikogrammatiline analüüs annab keelest täpsema pildi. Näiteks harjutatakse tavaliselt kõneviise või tegumoodi verbi muutmise kaudu ning põgusalt vaadatakse tegumoe ja kõneviisi väljenduslikke eesmärke. Siinse artikli tarbeks otsiti Keeleveebist sõna „lubama“ oleviku umbisikulise tegumoe vorme; selleks vaadati kolme registrit: ajakirjandustekste (Eesti Päevaleht), jututubasid ja doktoritöid. Allpool võrreldakse 23 esimese lause eitust ja jaatust.

Tabel 1. Sõna lubama oleviku umbisikulises tegumoes

\begin{tabular}{|l|c|c|}
\hline Register & Lubatakse & Ei lubata \\
\hline EPL & 14 & 6 \\
\hline Jututoad & 8 & 16 \\
\hline Doktoritööd & 21 & 2 \\
\hline
\end{tabular}

Ilmneb, et umbisikulise tegumoe eitust esineb selle sõna puhul kõige enam jututubades. Üsna tavaliseks osutub lause, kus ei lubata esineb koos da-infitiiviga: enam ei lubata vigiseda ka; mul ei lubata siin enam olla. Vestlejad on enamasti noored ning räägitakse endast ja oma kogemustest, sageli mainitakse selle sõna eitusvormi puhul tegevusi. Ajalehetekstides on aga $d a$-infintiivi kõrval kasutuses osastavas käändes nimisõnaline sihitis: Sarneti sõnul ei lubata üksnes rahalist sissemakset, vaid investeeritava summa kasutamine sätestatakse ostu-mü̈̈gi lepingusse tehtavate muиdatustega. Niisiis on neis tekstides juttu ka esemetest ja nähtustest, mida teismeliste vestluses aga sel moel ei leidu. Vormide leksikogrammatiline analüüs annab täpsemat teavet, mida vaadeldavate konstruktsioonidega tekstides väljendatakse. Just seesuguste näidete viimine õpikutesse ja nende seostamine asjakohaste korpuspõhiste harjutustega aitaks keeleteadlikkust parandada. Kui keemiatunnis paeluvad õpilasi laboritöö ja katsed, siis keele laboriks on tekstikorpused.

Leksikogrammatiline õppeviis on universaalne, kaasates ka teise emakeelega õppija (kes tänapäeval on sageli samas klassis), sest töö peamine 
meetod on uurida keelenäiteid ja teha nende põhjal järeldusi grammatika toimimise kohta. Tekstivalikul tuleks aga arvestada õppija võimeid ja eakohasust: noorematele sobivad jutustavad ja kirjeldavad tekstid, hiljem lisanduvad selgituste ja argumentatsiooni analüüs (Langer 1985). Tekstid erinevad domineeriva ajavormistiku, sidenduse, sõnaliigikoosluse jm tunnusjoonte poolest. Ühe võimalusena aitab vormivalikut ja tähendust koos õpetada ning mõtestada konstruktsioonigrammatika, mida tutvustab Kaia Kivitoa oma magistritöös (2015). Selles uuritakse mitmesuguste harjutustega näiteks teksti käändekasutuse tähendusi ning õpetatakse juhendavat teksti kirjutama: juhata loomaaia külastaja põhjaväravast elevantideni (ib. 67). Ühtlasi areneb selle meetodi abil oskus tekste kriitiliselt hinnata ja eri liiki tekste meisterlikumalt kirjutada. (Kivitoa 2015: 41)

Korpuste kasutamise kontekstis on leksikogrammatilise keeleõpetuse tõhusust uurinud Liu ja Jiang (2009), kes kasutasid poole aasta vältel avastusõppest lähtuvat andmepõhist õpet (ingl data-driven learning) ehk juhatasid õpilased korpuse abil grammatilisi struktuure uurima. Tulemus oli positiivne, õpilased hindasid autentse materjali ja konteksti kohalolu. Samas aga möönavad autorid, et radikaalne meetod, kus õpilased peavad ise toime tulema korpusest saadud andmetega, võib mõnele õpilasele raskusi tekitada (Liu, Jiang 2009: 75).

Jason Peppard kasutas andmepõhise õppe mõõdukamat varianti, kus keelematerjal oli enne ette valmistatud. Ta tegi katse ja õpetas grammatilisele struktuurile keskendunud kursust paralleelselt funktsionaalse leksikogrammatilise kursusega ning võrdles pärast õpilaste tulemusi. Leksikogrammatiline kursus oli efektiivsem, sest sõnade ja konteksti abil oli grammatilisi seoseid parem selgitada. (Peppard 2010: 46)

Bennett (2014: 8-11) lihtsustas andmepõhise õppe viise veelgi ja esitas kahese mudeli.

Isegi lihtsam viis võib võtta palju aega, ent võib pakkuda õpilastele vaheldust. Igasugune meetod ei tohiks muutuda üksluiseks, nii ei tasu ka andmepõhist õpet ainsana kasutada. 
Tabel 2. Andmepõhise õppeviisi keerukus

\begin{tabular}{|l|l|}
\hline Raskem viis & Lihtsam viis \\
\hline Küsi küsimus. & Küsi lihtne ja selge küsimus. \\
\hline Vali register. & $\begin{array}{l}\text { Tee ise konkordantsid, vali need näiteks } \\
\text { ajalehest. }\end{array}$ \\
\hline Vali korpus. & Kohanda read. \\
\hline $\begin{array}{l}\text { Vali konkordantsi programm, millega } \\
\text { kvantitatiivset analüüsi teha. }\end{array}$ & Vähenda ridu. \\
\hline $\begin{array}{l}\text { Analüüsi ridu kvalitatiivselt, jooni alla } \\
\text { 2-3 sõna paremalt ja vasakult. }\end{array}$ & $\begin{array}{l}\text { Valmista ridade põhjal harjutused } \\
\text { ja tööta klassi või grupiga. }\end{array}$ \\
\hline Tee harjutusi ja tegevusi. & \\
\hline
\end{tabular}

Korpusotsingud aitavad paremini näha ka keelereeglite rakendumist. Reegel võib kehtida töövihiku näitelausete puhul, kuid mitte reaalses tekstiolukorras. Näiteks selgitatakse sageli ${ }^{5}$ sidesõna $k u i$ komareeglit nii: koma tuleb kui ette siis, kui sellele järgneb öeldis, ja ei tule, kui tegemist on võrdlustarindiga. Päring Keeleveebi korpusest (Eesti Päevaleht 1995-2007) kuvab aga lause, mis võib tekitada segadust.

Tagasiostulepinguna vormistatud laenult maksab laenuvõtja intressi väärtpaberite ostu- ja müügihinna vahena: ta ostab need tagasi kallimalt kui müüs.

Nii ei saa selline lihtsustatud reegel tegelikult toimida, sest ka kõrvallause võib olla võrdluslause. Sama lause võiks lõppeda ka sõnadega kallimalt(, ) kui ta selle müünud oli. Pääseteena võib kasutada Ehala pakutud algoritmimist (2012: 626): „Kas kui alustab kõrvallauset? - Jah. - Järelikult koma tuleb.“

Praegu võivad korpuspäringud anda vastuseks liiga keerulisi lauseid, seega tuleks luua pedagoogiline, õpilaste sisendkeele korpus. Reppen ja Richards soovitavad grammatika õpetuses kasutada pedagoogilisi korpusi (2014: 10-11). Inglise keele kohta on nii õppijakeele kui ka sisendkeele korpusi (MICASE, MICUSP, COCA jt), mida on lihtne kasutada ja mis

\footnotetext{
5 Ei ole liialdus väita, et paljud otsivad keeleküsimustele vastust Google’ist või foorumitest (nt oli 23.03.2017 Google' is tehtud ,kui koma“-päringu neljas vastus Delfi Naisteka foorumist http://naistekas.delfi.ee/foorum/read.php?35,10685847). Ka Tallinna ülikooli eesti keele kirjaliku väljendusoskuse loengute kuulajad vastavad igal aastal kursuse alguses küsimusele keeleallikate kasutamise kohta, et pigem leitakse vajalik vastus guugeldades. ÕS-i kasutab umbes $10 \%$ kuulajatest.
} 
sisaldavad mitmesuguseid metaandmeid. Sotsiokognitiivsest aspektist lähtuv korpusuuring peab üksikute konkordantside otsimise asemel vajalikumaks koostada rohkete metaandmetega terviktekstikorpus (Scott 1997; Biber jt 1998: 30), mille žanrivalik võimaldaks teha adekvaatseid järeldusi tekstide grammatiliste tunnuste, sõnavara ja õigekirja kohta, mida eesti keele ainekava ette näeb.

Eestis on sellise korpuse vajadusele osutanud Helin Puksand ja Krista Kerge (2012), kes viitavad, et õpikute eakohase kvaliteedi analüüs ei ole võimalik, kui pole teada üldhariduse pakutav sisend (nt õpivara jm koolitekstide sagedussõnastik). Sama ilmneb õpilaste sõnavara arengu uurimisel: selle kvaliteeti ei saa hinnata, kui puudub võrdlus nimetatud sagedussõnastikega (Kerge jt 2014a).

Sellise ainekäsitluse jaoks on vaja täita lüngad tekstiliikide leksikogrammatilise eripära uurimises. Hoolimata Eestiski populaarsest korpusuurimisest ei ole meie korpuste fookuses otseselt eesti keele õpetus parema grammatikapädevuse kontekstis. Esimese suurema sammuna on loomisel emakeeleõppija korpus EMMA (Sõrmus, Lepajõe 2014), mis võimaldab tulevikus autentseid õpilastekste uurida ja tulemusi ka eesti keele õpivarasse tuua. Sisendkeele tekstide lisamist praegu aga eesmärgiks ei seata (ib. 213).

Õpitekste, sh ka autentseid rekontekstualiseeritud tekste ja nende keelelist eripära, on uuritud nii keerukuse kui ka sõnaliigitasakaalu poolest (Puksand, Kerge 2012), ent õpilasele suunatud autentsete tekstide leksikogrammatilist eripära seni Eestis uuritud ei ole, kuigi Meieri, Kerge ja Pajupuu jt eelviidatud uurimismaterjal pakub selleks häid lähtekohti.

Sisendkeele korpuse loomine ja korpuspõhine leksikogrammatiline õppeviis põhikooli eesti keele tundides tooks esile grammatiliste struktuuride avaldumise tekstiliigiti, mis vähendaks abstraktset grammatikakäsitlust, aitaks keele struktuuri ja toimimist paremini mõista ning avardaks žanripädevust, abistades ka õpikukoostajaid. Ka aitaks see õpet individualiseerida ja kaasata teise emakeelega õpilasi, sest eesti koolis ei õpi vaid eesti emakeele kõnelejad. Korpuspõhine leksikogrammatiline keelekäsitlus aitaks parandada keeleteadlikkust ning võib muuta keeleõpetuse tähendusrikkamaks ja õpilaskesksemaks. 


\section{Kokkuvõte}

Artiklis otsiti kirjanduse toel vastuseid kahele sõlmküsimusele: 1) kuidas toetada lingvistilise kirjaoskuse arengut ja jagada vastutus kirjaoskuse omandamise eest; 2) kuidas võimaldada grammatika ja tekstide koosõpet ning millised on vajakajäämised praeguses tekstikeskses keeleõpetuses. Kirjanduspõhisele arutlusele lisati sobivate õpimeetodite näiteid.

Tekstikeskne eesti keele õpetus lähtub peamiselt funktsionaalsest keelekäsitlusest ja kogemuslikust keeleomandamisteooriast nende mitmesugustes aspektides. Keel, st õigekeelsus ja stiilitunnetus omandatakse tekstidest, mis on kultuurilise taustaga sotsiaalsed toimingud. Mitmepalgeline tekstimaailm tagab lingvistilise kirjaoskuse, mis realiseerub suhtluses, seega võib öelda, et õigekeelsuse omandamine autentsete tekstide analüüsile ehitatuna või sellega toetatuna on suhtluseesmärkide saavutamiseks tarvilik.

Tekstid avalduvad žanritena, olukorra- ja kultuurisidusate tekstidena, niisiis peaks žanriõpetuse eesmärgiks olema žanriteadlikkus ehk oskus näha teksti, sh keelevahendite valiku ja ülesehituse taga konteksti, vastuvõtjat ja suhtluseesmärki. Seda aitavad kujundada näidetekeskne õpe, kus keelevalikuid ja ülesehituserinevusi uuritakse ja märgatakse ning leitud keelevahendite abil olukorra- ja eesmärgipärane tekst kirjutatakse.

Kirjaoskuse vastutuse jagamisel on piirimärgid eesti keele ja teiste ainete vastutuse vahel paika panemata, mille tõttu on vaja etnograafilist laadi uurimust, mis annaks täpsemat teavet eesti koolitundide tekstikäsitlusviisi kohta; tuvastama peaks tekstiõpetuse täpsed eesmärgid, õppetegevused ja tulemused aineti. Seesugune uuring annaks suuniseid õpetajakoolituse ja üldhariduse õppekavaarenduseks ning aitaks luua kirjaoskuse õpetamise metoodikat kõigi ainete vastutusel.

Teadusmõistelisele tasemele jõudmiseks ja soorituspinge ülal hoidmiseks peaks eesti keele tunnis olema kesksel kohal tekstide avastamine ja suhtluskoostöö, mida saab ellu viia mitme mõtlemist aktiveeriva meetodi, nagu näiteks induktsiooni ja avastusõppe abil. Ühtlasi tugevdaks see keele avastamise metoodikat, mis aitaks toetada ka mitmekeelse klassiruumi head toimimist.

Emakeeleõppija sisendkeelekorpuse loomine ja selle analüüs aitaks täita senised lüngad tekstiliigi ja grammatika ühitamisel. Sisendkeele korpusuuringu tulemusel saaks tekstiliike kirjeldada grammatiliste konstruktsioonide esinemuse järgi, nii väheneks abstraktne grammatikakäsitlus 
veelgi ning avarduks grammatika- ja žanripädevus. Ühtaegu abistaksid uurimistulemused ja kasutajasõbralik korpus õpikukoostajaid. Seejuures oleks vaja ka uusi metoodikakirjeldusi, sest korpusanalüüs kui uus õppeviis eesti keeles vajaks täpset juhendamist ja harjumist, kuid töö autentse keelematerjaliga võib teha keeleõpetuse tähendusrikkamaks ning õpilaskesksemaks.

Eelnev lõi teoreetilise raami uuringute jaoks, mille keskmes on tekstitöö koolitunnis. Teooriat rikastati praktiliste näidetega ja kirjeldati, kuidas koos õpetada žanri kompositsiooni ja keelekonstruktsioone, mismoodi läheneda keelele uurivalt ning kuidas kasutada õppetöös tekstikorpuseid. Praktika elluviimiseks oleks aga vaja täpsemaid sammsammulisi metoodilisi juhendeid, õppematerjale ning katsetusi, mis võiks pakkuda huvitavaid uurimisvõimalusi Tartu ja Tallinna Ülikooli eesti keele ja kirjanduse õpetaja eriala magistrantidele.

\section{Kirjandus}

Bennett, Gena R. 2013. Using Corpora in the Language Classroom. Corpus Linguistics for Teachers. Ann Arbor. Michigan University Press.

Biber, Douglas 1988. Variation Across Speech and Writing. Cambridge University Press. http://dx.doi.org/10.1017/CBO9780511621024.

Biber jt 1998 = Douglas Biber, Susan Conrad, Randi Reppen. Corpus Linguistics: Investigating Language Structure and Use. Cambridge University Press. http://dx.doi.org/10.1017/CBO9780511804489.

Biber jt 2002 = Douglas Biber, Susan Conrad, Randi Reppen. Developing linguistic literacy: perspectives from corpus linguistics and multi-dimensional analysis. - Journal of Child Language 29, 449-488.

Bruner, Jerome 1961. The act of discovery. - Harvard Educational Review 31, 21-32. https://digitalauthorshipuri.files.wordpress.com/2015/01/the-actof-discovery-bruner.pdf (04.01.2017).

Bybee, Joan L. 1998. The Emergent Lexicon. - Chicago Linguistic Society 34 (2). Eds. M. Catherine Gruber, Derrick Higgins, Kenneth S. Olson \& Tamra Wysocki, 421-436.

Carter jt 2000 = Ronald Carter, Michael McCarthy, Rebecca Hughes. Exploring Grammar in Context: Upper Intermediate and Advanced. Cambridge University Press.

Dean, Deborah 2008. Genre Theory: Teaching, Writing, and Being. NCTE.

EEÕS 2020 = Eesti elukestva õppe strateegia 2020. 2014. Haridus- ja Teadusministeerium, Eesti Koostöö Kogu, Eesti Haridusfoorum. Tallinn: 
Haridus- ja Teadusministeerium. https://www.hm.ee/sites/default/files/ strateegia2020.pdf (22.02.2017).

Ehala, Martin 2010. Lõimingust eesti keele õpetuses. - Lõiming. Lõiminguvõimalusi põhikooli õppekavas. Koost. ja toim. Juta Jaani, Liisa Aru. Tartu Ülikooli haridusuuringute ja õppekavaarenduse keskus, 75-101.

Ehala, Martin 2012. Kui vajalik on grammatika? - Keel ja Kirjandus 8-9, 614-628.

Ehala jt 2010 = Martin Ehala, Krista Kerge, Kersti Lepajõe, Kadri Sõrmus. Kõrgkoolide üliõpilaste eesti keele oskuse tase. Uuringukokkuvõte. Tartu Ülikool. Tartu. http://www.digar.ee/arhiiv/nlib-digar:102739.

Ehala jt 2014 = Martin Ehala, Triinu Laar, Karin Soodla, Kadri Sõrmus, Maigi Vija. Gümnaasiumi praktilise eesti keele kursuste metoodika õpik. Tartu: Tartu Ülikooli Kirjastus. http://dspace.ut.ee/handle/10062/41077.

Ehala jt 2015 = Martin Ehala, Krista Kerge, Kersti Lepajõe, Kadri Sõrmus. Kõrgkoolide üliõpilaste eesti keele oskuse tase. Kordusuuring. Uuringu kokkuvõte. Tartu Ülikool. Tartu. http://dspace.ut.ee/handle/10062/48709.

EKR 2007 = Euroopa keeleõppe raamdokument. Õppimine, õpetamine ja hindamine. Tartu: HTM, ERÜ, EKSA. https://www.hm.ee/sites/default/files/ euroopa_keele6ppe_raamdokument.pdf (04.01.2017).

Fairclough, Norman 2003. Analysing Discourse. Textual Analysis for Social Research. London, New York: Routledge.

GRÕK 2011 = Vabariigi Valitsuse 6. jaanuari 2011. a määrus nr 2 „Gümnaasiumi riiklik õppekava“" lisa 1 (muudetud sõnastuses). https://www.riigiteataja. ee/aktilisa/1290/8201/4021/2m_lisa1.pdf (04.01.2017).

Halliday, MichaelA. K. 1978. Language as Social Semiotic. London: Edward Arnold.

Halliday, Michael A. K. 1985. An Introduction to Functional Grammar. London \& New York: Routledge.

Halliday, Michael A. K. 2005 (1979). Modes of meaning and modes of expression: types of grammatical structure and their determination by different semantic functions. - On Grammar. Collected Works of M. A. K. Halliday 1. Ed. Jonathan Webster. London, New York: Continuum, 196-218.

Halliday, Michael A. K. 2005. On matter and meaning: the two realms of human experience. - Linguistics and the Human Sciences 1 (1), 59-82.

Halliday, Michael A. K., Christian M. I. M. Matthiessen 1999. Construing Experience through Meaning: A Language-based Approach to Cognition. London: Cassell.

Hennoste, Tiit, Kadri Muischnek 2000. Eesti kirjakeele korpuse tekstide valiku ja märgendamise põhimõtted ning kahe allkeele võrdluse katse. Arvutuslingvistikalt inimesele. Toim. Tiit Hennoste. (= Tartu Ülikooli üldkeeleteaduse õppetooli toimetised 1.) Tartu: Tartu Ülikooli Kirjastus, 183-317. 
Hunston, Susan, Gill Francis 1999. Pattern Grammar: A Corpus-driven Approach to the Lexical Grammar of English. Amsterdam: John Benjamins. http://dx.doi.org/10.1075/scl.4.

Johns, Tim 1988. Should you be Persuaded - Two Samples of Data-Driven Learning Materials. http://wordsmithtools.com/wordsmith/corpus_linguistics_links/Tim\%20Johns\%20and\%20DDL.pdf (29.06.2016).

Kalantzis, Mary, Bill Cope 2016. Pedagogy - New Learning. http://newlearningonline.com/learning-by-design/pedagogy (23.12.2016).

Kerge, Krista 2003. Keelenormi tänapäevane olemus. - Õiguskeel 5, 26-34.

Kerge, Krista 2005. Rühma- ja paaristöö ühiskonnaprotsesside ja tekstiteadmiste taustal. - Eesti keele ja kirjanduse õpetamisest koolis. Koost. Mari Kadakas. Toim. Katrin Kalamees. Abiks õpetajale. Riiklik eksami- ja kvalifikatsioonikeskus. Tallinn: Argo, 54-64.

Kerge, Krista 2007. Euroopa keeleõppe ühtne raamistik ja emakeel. - Oma Keel 1, 27-39.

Kerge, Krista 2010a. Tekstikeskne keeleõpetus põhikoolis. - Põhikooli valdkonnaraamat „Eesti keel ja kirjandus“. Koost. Mari Kadakas. https:// oppekava.innove.ee/tekstikeskne-keeleopetus/ (02.01.2017).

Kerge, Krista 2010b. Keeleõppe sotsiokognitiivsest paradigmast. - Gümnaasiumi valdkonnaraamat „Eesti keel ja kirjandus“. Koost. Mari Kadakas. http:/oppekava.innove.ee/wp-content/uploads/sites/6/2016/10/ Keele\%C3\%B5ppe_sotsiokognitiivsest_paradigmast.pdf (02.01.2017).

Kerge, Krista 2012. Let's talk linguistics. - Keel ja Kirjandus 8-9, 581-596.

Kerge, Krista, Hille Pajupuu 2010. Text-types in speech technology and language teaching. - Analysing data $>$ Describing variation. Proceedings of the XXVIII International Conference of AESLA. Eds. Jorge L. Bueno Alonso, Dolores Gonzáles Álvarez, Úrsula Kirsten Torrado, Ana E. Martínez Insua, Javier Pérez Guerra, Esperanza Rama Martínez \& Rosalía Rodríguez Vázquez. Vigo: Universidade de Vigo (Servizo de Publicacións), 380-390.

Kerge, Krista, Anne Uusen 2010. Toimingu- ja tekstikeskne maailm. - Tekstid ja taustad VI. Tekstiuurimus ja kool. Toim. Krista Kerge. (= Eesti keele ruum. Emakeeleõpetuse Infokeskuse toimetised 5.) Tallinn: TLÜ, 95-111.

Kerge jt 2014a $=$ Krista Kerge, Anne Uusen, Halliki Põlda, Helin Puksand Loovkirjutiste süntaksimuutujate areng teismeeas. - Emakeele Seltsi aastaraamat 59 (2013). Peatoim. Mati Erelt. Tallinn: Teaduste Akadeemia Kirjastus, 46-76.

Kerge jt 2014b $=$ Krista Kerge, Anne Uusen, Halliki Põlda. Teismeea loovkirjutiste sõnavara ja selle hindamine. - Eesti Rakenduslingvistika Ühingu aastaraamat 10. Toim. Helle Metslang, Margit Langemets, Maria- 
Maren Sepper. Tallinn: Eesti Rakenduslingvistika Ühing, 157-175. http:// dx.doi.org/10.3176/esa59.03.

Kikas, Eve 2013. Tunnetusprotsessid, motivatsioon ja uskumused. Nende iseärasused ja arengu toetamine kolmandas kooliastmes. - Õppimine ja õpetamine kolmandas kooliastmes. Üldpädevused ja nende arendamine. Toim. Eve Kikas, Aaro Toomela. Tallinn: Eesti Ülikoolide Kirjastus, 27-47. https://www.hm.ee/sites/default/files/oppimine_ja_opetamine_ iii_kooliastmes.pdf.

Kitsnik, Mare 2006. Keelekorpused ja võõrkeeleõpe. - Eesti Rakenduslingvistika Ühingu aastaraamat 2. Toim. Helle Metslang, Margit Langemets, Maria-Maren Sepper. Tallinn: Eesti Keele Sihtasutus, 93-107. http:// dx.doi.org/10.5128/ERYa2.07.

Kivitoa, Kaia 2015. Konstruktsioonigrammatika põhimõtete rakendamine teises kooliastmes. Teooria ja harjutusvara. Magistritöö. Tallinna Ülikool, humanitaarteaduste instituut. Tallinn: Tallinna Ülikool.

Knapp, Peter, Megan Watkins 2010. Genre, Text, Grammar. Technologies for Teaching and Assessing Writing. New Delhi: Orient Blackswan.

Koprowski, Mark 2005. Investigating the usefulness of lexical phrases in contemporary coursebooks. - English Language Teaching Journal 59 (4), 322-332. http://dx.doi.org/10.1093/elt/cci061.

Krogh, Ellen 2012. Writing in the literacy era: Scandinavian teachers' notions of writing in mother tongue education. - L1 - Educational Studies in Language and Literature 12 (special issue). A contribution to the inescapability of language. Eds. Iris Pereira, Brenton Doecke. 1-28.

Lepajõe, Kersti 2010. Eesti keele ainekava koostamise alused ja olulisemad muutused. http://oppekava.innove.ee/eesti-keele-ainekava-koostamisealused-ja-olulisemad-muutused/ (02.01.2017).

Lepajõe, Kersti 2011. Kirjand kui tekstiliik. Riigieksamikirjandite tekstuaalsed, retoorilised ja diskursiivsed omadused. (= Dissertationes philologiae Estonicae Universitatis Tartuensis 31.) Tartu: Tartu Ülikooli Kirjastus. http://dspace.ut.ee/handle/10062/22444.

Langer, Judith A. 1985. Children's sense of genre. - Written Communication 2, 157-187.

Liu, Dilin, Ping Jiang 2009. Using a corpus based lexicogrammatical approach to grammar instruction in EFL and ESL contexts. The Modern Language Journal 9, 61-7.

Martin, James R. 1997. Analysing genre: functional parameters. - Genre and Institutions: Social Processes in the Workplace and School. Eds. Frances Christie, James R. Martin. London: Cassell, 3-39.

Meier, Heidi 2003. Essee asend allkeelte tekstitüübivõrdluses. Magistritöö. Tallinna Pedagoogikaülikool, filoloogiateaduskond, eesti filoloogia osakond. Tallinn: Tallinna Pedagoogikaülikool. 
Miller, Carolyn 1984. Genre as social action. - Quarterly Journal of Speech 70 (2), 151-167. http://dx.doi.org/10.1080/00335638409383686.

Peppard, Jason D. I. 2010. Towards a Functional-Lexicogrammatical Syllabus. A dissertation. The School of Humanities of the University of Birmingham. Birmingham: University of Birmingham. http://asian-efl-journal. com/Thesis/Thesis-Peppard.pdf (02.07.2016).

Piits jt 2012 = Liisi Piits, Kaja Sarapuu, Terje Varul. Eesti keele õpik 5. klassile: uus õppekava. Tallinn: Avita.

Piits jt 2013 = Liisi Piits, Kaja Sarapuu, Terje Varul. Eesti keele õpik 6. klassile: uus õppekava. Tallinn: Avita.

PRÕK 2011 = Vabariigi Valitsuse 06.01.2011. a määruse nr 14 „Põhikooli riiklik õppekava“" lisa 1. https://www.riigiteataja.ee/aktilisa/1290/ 8201/4020/1m\%20lisa1.pdf\# (04.01.2017).

Puksand, Helin, Reet Bobõlski 2012a. Koma. 5. klassi eesti keele õpik. Tallinn: Koolibri.

Puksand, Helin, Reet Bõbõlski 2012b. Peegel 1. 7. klassi eesti keele õpik. Tallinn: Koolibri.

Puksand, Helin, Reet Bobõlski 2013. Punkt. 6. klassi eesti keele õpik. Tallinn: Koolibri.

Puksand, Helin, Reet Bõbõlski 2014. Peegel 2. 8. klassi eesti keele õpik. Tallinn: Koolibri.

Puksand, Helin, Reet Bõbõlski 2016. Peegel 3. 9. klassi eesti keele õpik. Tallinn: Koolibri.

Puksand, Helin, Krista Kerge 2012. Õpiteksti analüüs kirjaoskuse omandamise kontekstis. - Emakeele Seltsi aastaraamat 57 (2011). Peatoim. Mati Erelt. Tallinn: Teaduste Akadeemia Kirjastus, 162-217.

Põlda, Halliki, Katrin Aava 2016. Muutunud õpikäsituse keeleline konstrueerimine. - Eesti Rakenduslingvistika Ühingu aastaraamat 12. Toim. Helle Metslang, Margit Langemets, Maria-Maren Sepper. Tallinn: Eesti Rakenduslingvistika Ühing, 201-217.

Raidlepp, Margaret 2015. Emakeele õigekirja ja grammatika õpetamise viisid III kooliastmes. Magistritöö. Tallinna Ülikool, eesti keele ja kultuuri instituut. Tallinn: Tallinna Ülikool.

Ratassepp, Priit 2012 (2010). Lausetest tekstini. Eesti keele õpik 8. klassile. Tallinn: Avita.

Ravid, Dorit, Liliana Tolchinsky 2002. Developing linguistic literacy: a comprehensive model. - Journal of Child Language 29, 417-447.

Remmel, Nikolai 2008 (1971). Eesti keel õpilase pilguga. - Nikolai Remmel eesti keelele ja koolile. Artikleid ja bibliograafia. Koost. Viivi Maanso. Toim. Krista Kerge. (= Eesti keele ruum. Emakeele Infokeskuse toimetised 3.) Tallinn: Tallinna Ülikooli Kirjastus, 76-139. 
Reppen, Randi, Jack C. Richards 2014. Towards a pedagogy of grammar instruction. - RELC Journal 45 (1), 5-25.

Reppen, Randi, Shelley Staples 2016. Understanding first-year L2 writing: a lexico-grammatical analysis across L1s, genres, and language ratings. Journal of Second Language Writing, 17-35.

Richardson, Virgina 2003. Constructivist pedagogy. - Teachers College Record 105 (9), 1623-1640. http://www.learningdomain.com/constructivist_pedagogy.pdf (02.01.2017). http://dx.doi.org/10.1046/j.14679620.2003.00303.x.

Roio, Maire 2011. Emakeeleõpetus õpilaste arvamuses. Magistritöö. Tartu Ülikool, filosoofiateaduskond, eesti keele osakond. Tartu: Tartu Ülikool.

Scott, Mike 1997. PC analysis of key words and key key words. - System 25 (2), 233-245. http://lexically.co.uk/downloads/corpus_linguistics/ PC\%20Analysis\%20of\%20Key\%20Words\%20-\%20and\%20Key\%20 Key\%20Words.pdf (02.01.2017). http://dx.doi.org/10.1016/S0346251X(97)00011-0.

Sinclair, John 1991. Corpus, Concordance, Collocation. Oxford University Press.

Soodla jt 2013 = Piret Soodla, Olga Luptova, Helin Puksand. Suhtluspädevus. Õppimine ja õpetamine kolmandas kooliastmes. Üldpädevused ja nende arendamine. Toim. Eve Kikas, Aaro Toomela. Tallinn: Eesti Ülikoolide Kirjastus, 94-110. https://www.hm.ee/sites/default/files/oppimine_ja_ opetamine_iii_kooliastmes.pdf (07.05.2017).

Sõrmus, Kadri, Kersti Lepajõe 2014. Eesti keele kui emakeele õppija tekstikorpus EMMA. - Uurimusi keele omandamisest, õpetamisest ja korpustest. Toim. Krista Kerge. (= Tallinna Ülikooli eesti keele ja kultuuri instituudi toimetised 16.) Tallinn: Tallinna Ülikool, 205-227.

Toomela, Aaro 2013. Arengust, õppimisest, õpetamisest, pääsukestest. - Õppimine ja õpetamine kolmandas kooliastmes. Üldpädevused ja nende arendamine. Toim. Eve Kikas, Aaro Toomela. Tallinn: Eesti Ülikoolide Kirjastus, 9-26.

Tärk, Tiina 2008. Eesti keel tänase õpilase pilguga: Nikolai Remmeli katse 2008. - Nikolai Remmel eesti keelele ja koolile. Artikleid ja bibliograafia. Koost. Viivi Maanso. Toim. Krista Kerge. (= Eesti keele ruum. Emakeele Infokeskuse toimetised 3.) Tallinn: Tallinna Ülikooli Kirjastus, 140-151.

Weninger, Csilla 2010. The lexico-grammar of partnerships: corpus patterns of facilitated agency. -Text and Talk 30 (5), 591-613. http://dx.doi. org/10.1515/text.2010.029.

Wichmann jt 2013 (1997) = Teaching and Language Corpora. Applied Linguistics and Language Study series. Eds. Anne Wichmann, Steven Fligelstone, Tony McEnery, Gerry Knowles. London \& New York: Routledge. 


\title{
Text centered L1 instruction: Theoretical background, responsibility, methods
}

\author{
MERILIN ARUVEE
}

L1 teaching in Estonia has become text-centered, which stems from functional language theory and modern understandings of literacy that see a rich textual environment as the guarantee of both linguistic literacy and literacy in general. This prompts questions of methods, teaching principles, and approaches: what is the main focus of text instruction in L1 classrooms versus other subjects? Which methods allow text work and simultaneous development of grammar ability? This meta-methodological article focuses on those two main research questions and views them within the framework of constructionist pedagogy theories. The article describes the corpus-based lexico-grammatical approach to language teaching as one potential solution.

According to the conceptual framework of linguistic literacy, people acquire language from the linguistic environment surrounding them. Texts are formed within social situations and are viewed as genres which vary in contexts. Genres are taken in and produced systematically in school and therefore design linguistic literacy.

The responsibility for teaching literacy lies on every school subject, and in order to guarantee the fulfilment of this goal, clear landmarks between L1 and other subjects have to be set. This has not yet been done in Estonia. An exhaustive study which identifies the texts and teaching aims regarding text work in L1 and other subjects would provide an answer to the question.

Second, more effort must be made to create learner-centered classrooms, beginning from the known and moving towards new knowledge; this lies at the heart of constructionist pedagogy and cognitive development. One possibility is to improve inquiry-based learning, inductive reasoning and analysis of situative genres around us.

Third, Estonian L1 teaching requires more intensive corpus-based research in order to connect genres to grammatical features and more thorough methodological instructions in order to analyze texts from the perspective of linguistic features.

Fourth, many researchers and theorists declare that bringing corpora into classrooms offers authentic text material, which simplifies language analysis and connects the linguistic features to genres. The corpus-based lexicogrammatical approach has been proven to be more effective than abstract grammar teach- 
ing. Linguistic corpus research emphasizes corpora as a legitimate resource of authentic language which should be used by textbook publishers and teachers to tighten the connection between the language classroom and applied linguistics. The Estonian language lacks both a pedagogical intake language corpus and a thorough lexicogrammatical corpus study of L1 teaching, which could solve this issue, offering the tools for connecting authentic texts and their linguistic features.

Key words: sociolinguistic, systemic-functional language theory, L1 acquisition, linguistic literacy, text, functional grammar

Merilin Aruvee

humanitaarteaduste instituut

Tallinna Ülikool

Narva mnt 25

10120 Tallinn

merilin.aruvee@tlu.ee 